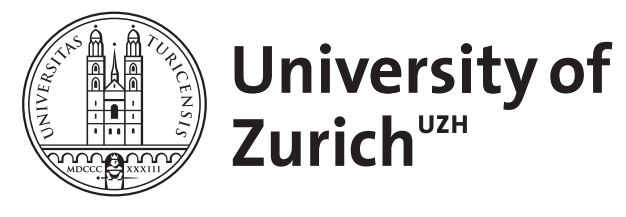

\title{
Standards and norms in the english language
}

Edited by: Locher, M A ; Strässler, J

\begin{abstract}
The theme of this collection is a discussion of the notions of 'norms' and 'standards', which are studied from various different angles, but always in relation to the English language. These terms are to be understood in a very wide sense, allowing discussions of topics such as the norms we orient to in social interaction, the benchmark employed in teaching, or the development of English dialects and varieties over time and space and their relation to the standard language. The collection is organized into three parts, each of which covers an important research field for the study of norms and standards. Part 1 is entitled "English over time and space" and is further divided into three thematic subgroups: standard and non-standard features in English varieties and dialects; research on English standardization processes; and issues of standards and norms in oral production. Part 2 deals with "English usage in non-native contexts," and Part 3 is dedicated to "Issues on politeness and impoliteness." The notions of standards and norms are equally important concepts for historical linguists, sociolinguists with a variationist background, applied linguists, pragmaticians, and discourse analysts.
\end{abstract}

Posted at the Zurich Open Repository and Archive, University of Zurich

ZORA URL: https://doi.org/10.5167/uzh-17138

Edited Scientific Work

Published Version

Originally published at:

Standards and norms in the english language. Edited by: Locher, M A; Strässler, J (2008). Berlin: Walter de Gruyter. 


\section{Table of contents}

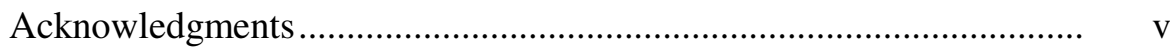

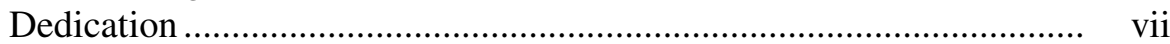

Tabula Gratulatoria .......................................................................... ix

Bibliography of Richard J. Watts' work .......................................... xiii

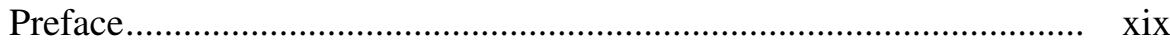

Chapter 1

Introduction: Standards and norms

Miriam A. Locher and Jürg Strässler.

\section{Part I. English over time and space}

Chapter 2

Swiss English, German English and American English:

In grammatical alliance against traditional British English?

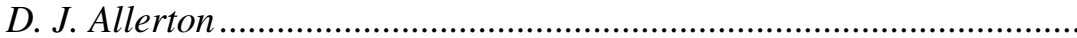

Chapter 3

Regional variation in English in the new millennium:

Looking to the future

Katie Wales

Chapter 4

The role of dialect contact in the formation of Englishes

Peter Trudgill

Chapter 5

Non-standardisation

Daniel Schreier.

Chapter 6

From 'standard' to 'nonstandard' grammar. New England in the days of Salem Witchcraft and the Civil War Adrian Pablé 


\section{Chapter 7}

The rise of prescriptive grammars on English in the $18^{\text {th }}$ century

Miriam A. Locher.

Chapter 8

Lest the situation deteriorates -

A study of lest as trigger of the inflectional subjunctive

Anita Auer

Chapter 9

The BBC Advisory Committee on Spoken English or

How (not) to construct a 'standard' pronunciation

Jürg Schwyter.

Chapter 10

Liverpool to Louisiana in one lyrical line:

Style choice in British rock, pop and folk singing

Franz Andres Morrissey.

\section{Part II. English usage in non-native contexts}

Chapter 11

'Standard' English, discourse grammars and English language teaching

Tony Bex.....

Chapter 12

Towards a new English as a Foreign Language curriculum for Continental Europe

Urs Dürmüller.

Chapter 13

Language learning and medium of instruction:

Understanding contemporary discourses and practices in Swiss schools and classrooms

Daniel Stotz. 
Chapter 14

Can academic writing style be taught?

Jürg Strässler

Chapter 15

Linguascaping Switzerland: Language ideologies in tourism

Adam Jaworski and Ingrid Piller.

Chapter 16

The rules of "Denglish"

Elke Hentschel.

\section{Part III. Issues on politeness and impoliteness}

Chapter 17

(Im)politeness in English as Lingua Franca discourse

Juliane House.

Chapter 18

How to be impolite: Rating offensive strategies

Mercedes Viejobueno, Carol G. Preston and Dennis R. Preston

Contributors

Contact information

Subject index 403

Author index 407 
Bereitgestellt von | UZH Hauptbibliothek / Zentralbibliothek Zürich Angemeldet Heruntergeladen am | 14.11.17 17:50 